O.O. МОМОТ, М.В. ГРИНЬОВА

\title{
ВПЛИВ СІМЕЙНОГО ВИХОВАННЯ НА ФОРМУВАННЯ КУЛЬТУРИ ЗДОРОВ'Я ОСОБИСТОСТІ ДИТИНИ
}

\author{
(C) Момот O.0., 2019 \\ http://orcid.org/0000-0001-9187-1036 \\ (C) Гриньова М. В., 2019 \\ http://orcid.org/0000-0003-3912-9023 \\ http://doi.org/10.34142/2312-2471.2019.61.15
}

У статті визначено та теоретично обтрунтовано пріоритет сімейного виховання на формування культури здоров'я особистості дитини як сукупність знань, умінь $i$ навичок ведення здорового способу життя, психологічне самовдосконалення, соияіальний та фізичний розвиток, щзо залежчть від традииійної складової ичього впливу, способу організації жсиття, участі обох батьків у вихованні, правильної організащії вільного часу сім'і, ставлення батьків до здоров'я. Культура сімейного виховання головним чином визначає культуру особистості дитини. Успіх сімейного виховання багато в чому залежить від організаиії домашнього життя, традицій сімейного життя. Здоров'я - основна загальнолюдська цінність, тому одним із пріоритетних напрямів культури здоров'я є створення стимулюючої, позитивної, здоров 'язберігаючої, духовної та морально-психологічної атмосфери в сім'ї, оволодіння необхідними знаннями, вміннями та навичками для збереження та змічнення здоров'я, забезпечення відповідних умов для навчання та фрормування фізично та психічно здорової людини, покликаних формувати здоровий світогляд, культуру здоров'я. Основна вимога до сімейного виховання - це вимога любові. Харчування відіграє важливу роль у формуванні культури здоров'я дитини. Воно має бути раціональним, врівноважсеним, помірним та різноманітним, изе перший ключ до здоров'я та добробуту, гарантія ефективності навчально-виховного прочесу. Роль сімейного виховання у сформованості культури здоров'я дитини визначається рівнем зміцнення здоров'я, вмінням уберегти й покращувати своє здоров'я та оточення і сприймати його як найвищу ичінність. Культура здоров'я сприяє формуванню особистості дитини як повноцінного члена суспільства, пристосованого до життя в изьому середовищі та здатного пристосовуватися до змін соиіуму.

Ключові слова: здоров'я, культура здоров'я, сімейне виховання, особистість дитини, сім'я.

\section{Moмot O., Grynova M. Influence of Family Education on the Formation of Health Culture for Child's Personality}

The article identifies and theoretically substantiates the priority of family education for the formation of a health culture for child's personality as a set of 
knowledge, skills and abilities to lead a healthy way of life, psychological selfimprovement, social and physical development, which depends on the traditional component of this influence, ways of organizing life, participation of both parents in education, proper organization of family free time, the parents' attitude to health. The culture of family behaviour determines mainly the culture of child's personality. The success of family upbringing largely depends on the organization of home life, traditions of family life. Health is a fundamental universal value, so one of the priority areas of health culture is to create a stimulating, positive, health-preserving, spiritual and moral-psychological atmosphere in the family, mastering the necessary knowledge, skills and abilities to preserve and strengthen health, providing appropriate conditions for training and formation a physically and mentally healthy person, designed to form a healthy worldview, health culture. The main requirement for family upbringing is the requirement of love. Nutrition plays an important role in shaping a child's health culture. It should be rational, balanced, moderate and diverse, it is the first key to health and wellbeing, a guarantee of the effectiveness of the educational process. The role of family upbringing in the formation a child's health culture is determined by the level of health promotion, the ability to preserve and improve health and the environment, and to perceive it as the highest value. The health culture contributes to the formation child's personality as a full member of a society, adapted to the life in this environment and able to adapt changes in society. family

Key words: health, health culture, family upbringing, child's personality,

Постановка проблеми. Формування культури здоров'я особистості нагальна проблема сучасної психолого-педагогічної науки й практики, адже здоров'я - основа благополуччя та розквіту нації, джерело щасливого повноцінного життя.

Аналіз останніх досліджень і публікацій. Порушенню проблематики зі збереження здоров'я людини у світовій педагогічній думці сприяли праці античних філософів доби Відродження (Т. Кампанелла, I. Меркуріаліс, Т. Мор, Ф. Рабле, В. Да Фельтре та ін.), педагогів Нового і Новітнього часу (М. Монтессорі, Й. Песталоцці, С. Френе, Р. Штайнер та ін.).

Становлення й розвиток проблеми здоров'язбережування людини у вітчизняній педагогіці пов'язані 3 народними традиціями, 3 першими педагогічними творами доби Київської Русі (зокрема 3 «Повчанням дітям» Володимира Мономаха), виховним досвідом козацької педагогіки, педагогічною діяльністю братських шкіл і Києво-Могилянської академії. Фундаментальні наукові розробки 3 теорії та практики формування здорового способу життя належать видатним науковцям: О. Бутовському, В. Короленку, П. Лесгафту, Т. Лубенцю, А. Макаренку, С. Русовій, Г. Сковороді, В. Сухомлинському та ін.

Виділення невирішених раніше частин загальної проблеми. Соціальна і практична значущість, а також необхідність виховання здорового способу життя молодого покоління, недостатня наукова розробленість проблеми зумовили 
вивчення питання впливу сімейного виховання на формування культури здоров’я особистості дитини.

Мета статті - визначення та теоретичне обгрунтування пріоритету сімейного виховання на формування культури здоров'я особистості дитини.

Виклад основного матеріалу. Виховання - соціально й педагогічно організований процес створення оптимальних умов для формування людини як особистості [3, с. 180]. Мета виховання - це, насамперед, визначені результати розвитку та формування особистості, яких прагнуть досягти в процесі виховної роботи.

Головна вимога до сімейного виховання - це вимога любові. Любов може досягти виду досконалої повноти життєвої взаємності й через це ставати вищим символом ідеальних відносин між особистим початком та суспільним цілим [7].

На думку українських педагогів та філософів, любов - основа багатого духовного життя людини: «не може бути любові без елементарної людяності, не можуть бути доступними високі ідеали безсердечній людині, яка неспроможна до тонких переживань. Безсердечність породжує байдужість до людей, байдужість самолюбство, самолюбство - жорстокість» [1, с. 139].

Глибокий, постійний психологічний контакт із дитиною - це універсальна вимога до виховання, що однаковою мірою може бути рекомендована всім батькам, у особистісному вихованні кожної дитини. Саме відчуття й переживання контакту з батьками дають дітям можливість відчути й усвідомити батьківську любов, прихильність і турботу [2, с. 161].

Формування особистості - процес соціального розвитку молодої людини, становлення ii як суб'єкта діяльності, члена суспільства, громадянина. Це надання певної форми, завершеності процесу становлення людської особистості, досягнення нею рівня зрілості, стабільності [5, с. 59].

Формування здоров'я особистості дитини $є$ одним із найважливіших напрямків сімейного виховання. Підгрунтям етикету сімейних відносин $\epsilon$ моральний принцип, який полягає в тому, що вдома не можна поводитися, «як заманеться». Навпаки, саме культура спілкування подружжя в сім’̈̈, їхня поведінка в побуті - один із головних критеріїв здорового способу життя.

Варто пам'ятати одне прислів'я: «Якщо ви не хочете, щоб діти повторювали ваші помилки, не допускайте їх». Батьки - вихідна модель для наслідування та приклад для дітей (якщо вони займаються вихованням) [9, c. 108]. Приклад - це метод виховання, який передбачає організацію взірця для наслідування з метою оптимізації процесу соціального успадкування [3, с. 205]; це метод впливу на свідомість, почуття, поведінку особистості через наслідування; виховний вплив прикладу - це своєрідна наочність у виховній роботі [4, с. 135].

Успіх сімейного виховання значною мірою залежить від організації домашнього побуту, традицій сімейного життя. Здоров’я - фундаментальна загальнолюдська цінність, тому одним із пріоритетних напрямків формування культури здоров'я $є$ створення стимулювальної, позитивної, здоров’язбережувальної, духовної та морально-психологічної атмосфери в сім'ї, 
оволодіння необхідним обсягом знань, умінь i навичок збереження та зміцнення здоров'я, забезпечення відповідних умов для навчання та формування фізично i психічно здорової особи, покликаних формувати здоров' язбережувальний світогляд, культуру здоров’я [6, с. 148].

Важливу роль у формуванні культури здоров'я особистості дитини виконує харчування. Воно має бути раціональним, збалансованим, помірним i різноманітним, це перший ключ до здоров’я та гарного самопочуття, гарантія ефективності виховного процесу. Раціональне збалансоване харчування - це фізіологічно повноцінне харчування людини з урахуванням iï статі, віку, характеру праці, кліматогеографічних умов та індивідуальних особливостей [8, с. 399].

Пропонуємо поради та рекомендації для молодого покоління, батьків, які передбачають дотримання принципів раціональності, збалансованості, помірності й різноманітності [6, с. 252-253], а саме:

1. Вживайте лише низькокалорійну та нежирну їжу (додайте рибу та жирні кислоти Омега-3 до свого раціону).

Якщо Ваша ідеальна вага менше 61 кг, то з’їдайте на сніданок по 200 ккал; якщо понад 90 кг - то 300 ккал. Якщо ж вага, до якої Ви прагнете, знаходиться між цими двома цифрами, то помножте іiі на 3,3 і отримаєте необхідну цифру. Намагайтеся їсти корисну їжу: свіжі овочі і фрукти, нежирне м'ясо. Головне - зберегти баланс у вживанні протягом дня білків, жирів та вуглеводів: їхня кількість повинна бути приблизно рівною.

2. Обов’язково снідайте (неправильний сніданок або його відсутність призводить до ожиріння).

Сніданок - важливий прийом їжі, має становити третину добового раціону і бути ситним. Саме вранці людина отримує заряд на весь день, так як правильний сніданок збільшує працездатність.

3. Пийте воду, щоб скинути вагу.

Вода входить до складу харчових продуктів (питна - самостійний харчовий продукт) і складає основну масу тіла людини - 58-67 \%. Вода в організмі людини має велике значення, вона - середовище, де відбуваються складні біохімічні процеси, - в клітинах, тканинах і органах. Людина не може тривалий час існувати без води. Якщо без їжі, але при споживанні води, вона може прожити близько місяця, то без води - 2-5 днів. Вода повинна бути нешкідливою за хімічним складом і безпечною в епідеміологічному відношенні. Зовнішній вигляд води не завжди говорить про ii якість. Звичайно, вода каламутна, така, що має неприємний запах або незвичайний колір, завжди підозріла.

4. Їжте через кожні 3-6 годин.

Для травлення та засвоєння поживних речовин (джерел енергіi) має бути чіткий розпорядок у прийомі іжі. Інтервали між прийняттям їжі - 3-6 годин. Обов'язкова умова повного засвоєння поживних речовин - смакові властивості їжі. 
Вживання тих самих страв із дня на день призводить до різкого зниження апетиту, зменшення виділення травних соків. Харчування влітку та взимку мусить принципово відрізнятись. У зимовий період при низьких температурах організм витрачає більше енергії для підтримки температурного балансу, тому їжа в цей період повинна мати більшу енергетичну цінність. Улітку, коли діяльність травних залоз через спеку різко знижується - рекомендована їжа, яка містить легкозасвоювані, необхідні для організму поживні речовини [10, с. 15].

5. Правильно організуйте свій режим харчування.

Дотримуватися раціонального режиму харчування просто:

- вживати їу відповідно до біологічних ритмів організму;

- кількість прийомів їжі - 3-4 рази;

- інтервали між прийомами їжі - 3-6 годин.

Висновки. Отже, культура здоров'я - сукупність знань, умінь і навичок ведення здорового способу життя, психологічного самовдосконалення, соціального та фізичного розвитку. Роль сімейного виховання у сформованості культури здоров'я дитини визначається рівнем зміцнення здоров'я, вмінням уберегти й покращувати своє здоров'я та оточення i сприймати його як найвищу цінність. Культура здоров'я сприяє формуванню особистості дитини як повноцінного члена суспільства, пристосованого до життя в цьому середовищі та здатного пристосовуватися до змін соціуму.

Перспективи подальших наукових пошуків убачаємо у розширеному вивченні різноманітних особливостей, ознак, характеристик питання впливу сімейного виховання на формування культури здоров'я особистості дитини.

\section{Лimepamypa}

1. Гончаренко Н. С. До питання формування в підлітків моральних якостей. Таврійський вісник освіти. 2004. № 1(5). С.139.

2. Гром С. Сімейне виховання та його вплив на морально-особистісне зростання дошкільників. Молодь і ринок. 2012. №2 (85). С. 160-166.

3. Кузьмінський А. І., Омеляненко В. Л. Педагогіка: підручник. Київ: Знания-Прес, 2003. 418 с.

4. Лозова В. І., Троцко Г. В. Теоретичні основи виховання і навчання: навч. посіб. 2-е вид., випр. і допов. Харків: ОВС, 2002. 400 с.

5. Мойсеюк Н. Педагогіка: навч. посіб. 5-е вид., допов. і перероб. Київ., 2007. 656 с.

6. Момот О. Теорія і практика виховання майбутнього вчителя в умовах створення здоров'язбережувального середовища вищого навчального закладу: дис. ... докт. пед. наук: 13.00.07 «Теорія та методика виховання». Полтава, 2020. 552 c.

7. Попович Л. М. Любов - світле почуття чи розлад особистості. Психологія [Електронний ресурс]. URL: http://medpsyhology.pp.ua/lubovpochutta-rozlad (дата звернення: 6.8.2019). 
8. Присяжнюк С. І. Фізичне виховання: навч. посіб. Київ: Центр учбової літератури, 2008. 504 с.

9. Цьось А. В., Балахнічова Г. В., Заремба Л. В. Сучасні технології викладання спортивних дисциплін: навч. посіб. Луцьк: ВНУ ім. Лесі Українки, 2010. $132 \mathrm{c}$.

10. Чельник К. Харчування дітей у школі - як не нашкодити?. Відкритий урок : розробки, технології, досвід. 2008. № 2. С.14-15.

\section{References}

1. Goncharenko, N. S.(2004). To the formation of moral qualities of adolescents. Taurian Bulletin of Education. № 1 (5), 139. (in Ukrainian)

2. Grom, S. (2012). Family education and its impact on the moral and personal growth of preschoolers. Youth and the market, 2 (85), 160-166. (in Ukrainian)

3. Kuzminsky, A. I., Omelyanenko, V. L. (2003). Pedagogy: a textbook. Kiev: Knowledge Press. (in Ukrainian)

4. Lozova, V. I., Trotsko, G. V. (2002). Theoretical foundations of education and training. (2nd ed., ed. and add.). Kharkiv: OVS. (in Ukrainian)

5. Moiseyuk, N. (2007). Pedagogy. (5th type.). (in Ukrainian)

6. Momot, O. O. (2020). Theory and practice of educating future teachers in terms of creating a health-preserving environment of higher education. Doctor's thesis. Poltava: ONTU (in Ukrainian).

7. Popovich, L. M. Love is the light or the senses. Psychology [Electronic resource]. URL: http://medpsyhology.pp.ua/lubov-pochutta-rozlad (in Ukrainian)

8. Prisyazhnyuk, S. I. (2008). Physical education. Kiev: Center for Educational Literature. (in Ukrainian)

9. Tsos, A. V., Balakhnichova, G. V., Zaremba, L. V. (2010). Current technologies for teaching sports disciplines. Lutsk: VNU im. Lesi Ukrainka. (in Ukrainian)

10. Chelnik, K. (2008). Children's eating school: how not to harm?. Introductory lesson: box, technology, experience. №. 2, 14-15. (in Ukrainian). 